\title{
Theistic and Socionomic-Origin of Philosophy
}

\author{
Charles Ogundu Nnaji \\ Department of Religion and Philosophy, University of Abuja, Abuja, Nigeria \\ Email: Economos34@yahoo.com \\ Received November 20 $0^{\text {th }}$, 2012; revised December 22 ${ }^{\text {nd }}, 2012$; accepted January $7^{\text {th }}, 2013$
}

\begin{abstract}
This study directly touches on the origin and true meaning of philosophy from "Philos-Friend or loving and Ophis-Deceit" which means human reasoning or lover of deceit or false wisdom (not love for wisdom), we can better explain what Philosophy is all about from this brief etymology.
\end{abstract}

Keywords: Theistic; Socionomic; Origin; Philosophy; Humanties

\section{Brief Introduction to the Study}

Theistic philosophy is a second thought alternative to what professor Maduabuchi Dukor called "Theistic Humanism" especially since Humanism itself is a philosophy or believe system that focuses on human conditions or welfarism rather than on metaphysical existential arguments which (honestly) human reasoning abilities cannot yet decode or comprehend. While (Dukor's) Humanism in relation to the African is theistic, this paper's position is that the Theistic Humanism of the average African is not necessarily a theistic-Humanism, but a theistic philosophy since such belief systems are not really existential, but inherited beliefs, or worldviews that have no practical legacies, proofs or evident results.

\section{Objectives of the Study}

The study briefly touches the origin and true meaning of philosophy from "Philos" (love) and "Ophis-deciet” (Snakle) which collectively means Human reasoning (Newman, 1983) so that we can connect it to what Theistic-Humanism and Theistic philosophy should be.

This study attempts to show that what Dubor called African Theistic Humanism is merely a religious theistic-philosophy which has no evident practical legacies since Humanism is often accompanied by practical proofs with socionomic or sociological results that speaks volumes; especially, if the lofty Humanistic African ideologies being peddled about are anything to go by, then levels of developments in African societies should have far exceeded what they are currently.

Hence, this study rather than analyse points out that what we often present as African ideologics thought patterns, belief systems and worldviews are mere philosophies, reasonings ideas or ideas of best possible worldly which often run short of realities since the humanist or philanthropic ideas or philosophies of Africans rarely get praticalised just as a recent radio programme pointed out that Africans spend millions of Naira burying the dead rather than spending the millions on such people while they were still alive

\section{Focus of the Study}

This study draws attention to the difference between Theistic Humanism and theistic philosophy, especially that what we call "theistic Humanism" is mere socionomic spiritual or theistic philosophy or traditional practises, i.e. human religious beliefs presented as ideologies and philosophies, not forgetting that philosophies remain ideologies until put into practice (pragmatism).

\section{Statement of the Problem of Study}

Part of problems in philosophy is that philosophers often present positions and ideologies as if they are established realities: if that be the case, then philosophy has made itself science. That you taught of something as a best possible reality does not make that ideology or position a reality. Surely many philosophers are likely not going to agree with this study that many issues they present as a peoples' philosophies are truly not socionomic or physical realities just as a writer questioned the reality of Socrates: i.e. did Socrates and Pythagoras ever exist: Even if they existed, are classical Greek realities the same as contemporary African Traditional realities.

\section{Methodology}

The research consulted relevant literature, particularly Greek language texts and etymologies, including the Greek language. New Testament gave us the true meaning of the word philosophy. Greek English Lexicons and Ancient Greek language vocabularies not forgetting contemporary works in African philosophy were also consulted.

\section{Definition of Terms}

1) Theistic: The word theistic is the adjective of the Greek "Theos" i.e. "God". Hence, theism means believe in God, while theistic means the qualities of divinity or God. Theistic connotes relatedness to God (not God), rather it involves Godly human activities and ideas including theistic or religious human philosophies and ideologies (Metzger, 2001).

2) Humanism: Humanism comes from Human: Human is from Homo which means the same (Newman, 1983) or the same kind, type or specie while sapiens is the human or mankind in that specie. Humanism is the philosophical position that the Human (or existential) welfare (or condition should be focused on, rather than on incomprehensible metaphysical issues (Hawkins, 1995). 
3) Theistic Humanism: Theistic Humanism according to Dukor refer to the theistic nature and origins of African philosophy or worldviews which necessarily does not trickle down to the sociological or socionomic practicalities expected from the ideology

4) Theistic Philosophy: Theistic philosophy simply means Philosophical positions that are religious or socionomic e.g. my philosophy or belief is that God exists; which means that I am not arguing if God exists or not; My position or philosophy is that I already believe that God exists: Is that not philosophy; especially peoples philosophy that consists in practical traditional religious practices that constitute their own philosophy. This writer calls it socionomy. Philosophy can also be highly religious, not just only abstract thinking or argument.

5) Socionomic-Philosophy: Socionomy simply means the positive and negative contributions of Religion in the history of human societies (Nnaji, 2012. "psychonomy and socionomy in the origin and true meaning of philosophy”). Socionomic philosophy states that whatever philosophical labeling as society or people have been given must correspond to the physical realities of such a people's practises, especially that African philosophy is socionomic, i.e. societies controlled by intra-universally accepted religious beliefs and observances whereby the African primarily beliefs that the spiritual or metaphysical controls the physical. Unfortunately, philosophy today has been blindly presented by philosophers as a field of study that primarily has nothing to do with God and Religion, but has so much to do with science and investigation. But then that is not what philosophy means; philosophy is not definite, philosophy has no position, rather it has positions which are beliefs that are subject to investigation rather than verification. Philosophy investigates rather than verifying science has laboratories for verification through experimentation which establishes Truth rather than speculative reasoning. Philosophy has no laboratory since it is not science, hence it cannot through human reasoning but physical experimentation once philosophy breaks away from its human reasoning, then it is no more philosophy since philosophy simply makes human reasoning or uses human reasoning to investigate and solve all questions and problems in human existence (please see below "Origin and definition of the word Philosophy).

\section{Literature Review}

It is strongly believed that the word "Philosophy" did not exist in the Socratic-era, rather the initial name or labeling of the wandering logikos, i.e. argumentators was "sophists or sophronas (Brown, 1990) Sophosteros and sophroneo which-literally means "wiser" wiseman or people who use human reasoning or wisdom to answer questions of existence (Newman, 1983: pp. $165,177)$ Another word for wisdom in Greek is Noia-Nosis or Nimos; the Greek English Interlinear New Testament did not use "Sophos or Sophia" for wisemen, rather the word used is "phronimos" which means "wisemen or the wise" (Brown, Comfort et al., 1990). The original Greek language New Testament clearly shows that Jesus did not often use Sophia from Ophis (snake) but he used phronimos from Phren i.e., spiritual wisdom or prudent. Lk 12:42, Mtt 24:45 etc. (Metzger, 2001: p. 71). "Phronimos" did not metamorphose into the word "philosophy". The point is this, Sophia means human snake, i.e. false wisdom-serpentine-crafty and deceitful wisdom. Sophy or Ophis means snake or serpent, while Nosis, Nimos or Nouma means spiritual knowledge-Divine wisdom, understanding or Divine mysteries; This was the origin of the mystery-Gnosis or Gnosticism (Mccain, 2005; see also Newman, 1983). Hence, in coining the word "philosophy" Greek Sophists had to make a clear demarcation between Divine wisdom (Nosis, Nimos or Phronimos-Pnouma) and "Sophia or Sophos" (i.e. serpent) which clearly and indisputably means Human wisdom crafty and cleverness (see Aland \& Newman, 1983: p. 194; and Metzger, 2001: p. 71 etc.). This clearly says that the word "Philosophy” points to human reasoning. It has nothing to do with Divine wisdom being the reasoning why writers of the New Testament did not use the word philosophy to refer to divine wisdom: The few who did in the epistlers did so out of poor grasp of the Greek language "Phronomos" was constantly used, while Philosophy was mentioned only in Acts 17 and Colosians 2:8.

\section{Theistic Humanism-Analytical Reaction}

Though I have not fully understood what Prof. Dukor means by Thestic Humanism, It seems to me that the phrase "Theistic Humanism” strongly agrees that humanism (i.e. human welfarism) cannot be free from theistic (i.e. supernatural) influences especially since the metaphysics of ontology, cosmology and cosmogony often finally ends at the dead end of a necessary being incomprehensible, inexplicable and necessarily metaphysical, psychic or supernatural, since anything which cannot be explained must necessarily be mystical, numinous or spiritual. Theistic humanism as presented by Prof. Dukor simply means that humanism in African philosophy is inevitably theistic or spiritual, or more appropriately in philosophical language, it is metaphysical, and psychologically it is "metapsychic". The theistic nature of African philosophy has its origins in the endemic general belief system of virtually all Africans that existence has spiritual origins and it is not possible for existence to have been the product of accident or chance, especially that the spiritual controls the physical which is the world of ideas (remember philosophy hates using the word "spirit”). If African humanism is inevitably theistic, it simply means that man as the nucleus or central focus of African philosophy (or world view) is a psychic or spiritual product which completely draws African philosophy into a humanism that is inevitably theistic. If philosophy must remain credible, Its substance and method must be goal-getting or objective, rather than what the New Testament Greek called “sesophismenos”, i.e. cleverly-crafted (2 Peter 1:16) or invented stories and arguments (Dialegeto) which often leaves the substance while chasing shadows, especially shadows of anti-thesis (opposition) philosophy which often denies anything Religion in its bid to present philosophy as having nothing to do with Religion even when philosophy itself means belief system, which can be spiritual, scientific or sophist. When someone asks you what your philosophy of life is, it simply means, what do you believe in (please see Charles Ogundu Nnaji, 2012; the Etymology and True meaning of the word "philosophy”; Theometry, Abuja) Chapter one etc.

\section{Analysis of Chapter Three of Prof Dukor's Theistic Humanism of African Philosophy}

\section{African Cosmology, Ontology and (Cosmogony)}

This chapter dwelt on African cosmology, ontology and cosmology, which Dukor (2010) called “An exposition of Af- 
rican myths about God...” (p. 110).

This is in relation to the concepts of myth and the relationship between African cosmology and the unified field theory. Dukor subscribes to cosmology as the science of the universe and part of creation, while ontology is metaphysic i.e. the nature and essence of things especially God as a necessary being. Does anything exist necessarily? Is it necessary for something to exist, i.e. must God exist. Must there be a God? It is concerned with the existence of material objects, minds, persons, universals, numbers and facts etc.

"In the history of western philosophy cosmological argument for the existence of God is believed to have originated with Aristotle. The ontological argument for the existence of a supreme deity was a predominant intellectual question in a whole spectrum of ancient Greek philosophy. It argues that God exists necessarily: When Xenophanes in ancient Greek period was mentioning God, he was referring to him as a necessary being. The supreme deity in Socrates world of forms, called the demiurge is a necessary being” (Dukor, 2010: p. 110).

Other prominent philosophers who focused on the existence of God were medieval European philosophers like St. Thomas Aquinas (1224 CE), St. Augustine (d430 CE) St. Anselm of Canterbury (1033 CE) etc. They all worked on proving that God exists.

This chapter notes that European and other western writers often label African Religious practices as pagan, animist, heathenist and idolatry, which is very wrong (see Aland \& Newman, 1983; Pagan, i.e. deceit (p. 130). What Europeans call pagan are worldviews, belief systems or philosophies which present the African philosophy or belief system as superstitiously or deceitfully theistic or superterranean (p. 111). The African believes in the personification of nature, especially that the divinity of nature and all humans have vital souls, forces or spirits residing in them. Dukor cited Geofrey Parinder as observing the Igbo worldview or philosophy as being highly spiritual. Religion permeates every aspect of the Igbo life; hence Africans are incurably religious. Therefore African spirituality or metaphysics is indisputably (African) theistic philosophy. K. C. Anyanwu, Edwin Smith, John Mbiti, Malagasy myths. Buganda, Zulu, Ashante, Ngombe of Congo other mythical worldviews were also highlighted in this chapter.

\section{Myth and Science (See Iloyd Thompson, 1990)}

Dukor looked at "Myth" in African belief systems. Surely, African beliefs and customs are replete with myths and what science and philosophy call "fables and doubtful fairytales". Thinkers, however quarrel with dictionary definitions of myths. Anthropologists and Philosophers argue that limiting myths to stories of gods and heroes removes legends, and folktales through which historiography can reconstruct the past or history of Africa. Example, the Yoruba god, shango had existed physically as a human being with extraordinary powers, hence he is more of a historical figure rather than myth. Also the Igbo and Mende (Sierra-Leone) have ideas of God that should not be seen as myths but realities: when parapsychologists treat myths as dream, they forget that knowledge of hierarchical social stratas lost in the distant past cannot be retrieved through dreams. Dukor citing Alasdair Maclintyre and WKD Guthre sees the emergence of philosophy and science as beginnings of the rejection of Greek mythologies of gods and goddesses for a more systematic culture of reasoning especially questioning the existence of those gods etc., pp. 121-123 etc.

The emergence of philosophy as rejection of Greek myths of gods, including questions of the existence of those gods and goddesses, highlighted in Nnaji (2012) in The Origin and True meaning of Philosophy, specifically Pauline passages (Col 2:8, 1 Tim. 6:20 etc.) see also 1 Cor. 17:18, Isaiah 29:14 which strongly condemned philosophy as challenging God, proceeded to call philosophy empty deceit, foolish and stupid arguments, especially deceit called knowledge (i.e. Gnosis: 1 Tim. 6:20).

\section{Pathological Traditionalism and Igbo Metaphysics}

Dukor says that pathological traditionalism simply means African belief systems handed over many centuries while retaining its inconsistencies and undesirable cultic practices which consistently portrays it as heathenistic, i.e. dirty and spurious. He called it ... “crisis ridden” (p. 128). Though Africans have not seen the worship of God and divinities as the crisis in traditionalism, rather they are unquestionable integrates in African customs and traditions, through ritual killings, which are clearly murders that cannot be swept under the carpet. Some tradition have attempted to explain away such killings as customs handed down under customary humanism. To confirm the crisis ridden and undesirable nature of ageless African traditions and customs, Prof. Dukor narrated his grand father's confession that the work of a traditional spiritual head is so burdensome and implicative that the man urged his children to embrace Christianity. Dukor's grandfather's philosophical poem is titled "The muse of truth oracle" for Gbusaizu Dukor (18301958) Gbusaizu Dukor is Prof Dukor's grandfather. This tradition was narrated by Cyril Dukor (1916-2001) Prof Dukor's father. The poem generally highlighted the burden in being a high priest of the gods in his duty as custodian of truth received from God the supreme deity.

According to Dukor...

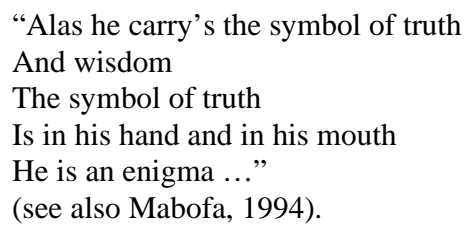

\section{A Triple Heritage}

1) The triple heritage discus arrests syncretic practices of merging Christianity, African traditionalism and Islam in one compromising-individual, described by philosopher Gbusaizu Dukor, as contamination of varying traditions which should not be distorted by alien cultures. Prof. Dukor cited Olu Holloway as an example of a compromised Christian who is the district grandmaster of the freemason in Nigeria and the Olori Oluwo of the Reformed Ogboni fraternity (ROF). Holloway thus exemplifies a Christian still deeply involved in traditional and Ogboni cultic practices, which Gbusaizu Dukor 1830 to 1958 is strongly against. "Tripple Heritage" is simply another technical word for syncretism which means simultaneous adherence of an individual to multiple religious practices and traditions: This which some opinions seriously frown at.

2) From the triple heritage, Dukor plunged into what he 
called the Noumenal (spiritual) substratum of the ephemeral in the question of the enculturation of African philosophy, i.e. foreign cultures have seriously influenced African world views. He touched on recent archaeological excavations in Igbo-Ukwu and Nri-Igbo which clearly show that Ibo-civilization is not inferior to that of Egypt, Greece and Samaria (p. 147).

3) He then discussed theistic panpsychism which is akin to animism (Nnaji, 2010) in that it is the belief that in every being or object there is a vital power, soul or spirit immanent-existing-in those objects (p. 148) i.e. Ibos and Africans don't worship empty objects but believed powers in those objects.

4) On theodicy, i.e. problem of evil, Prof. Dukor says that Igbo metaphysics and Augustinian theodicy believe that God did not create evil, but that evil is man-made and that some evil are attributable to some gods and misguided divinities (p. 153).

5) Dukor's logikos of an existing God in Ibo-metaphysics is that there is necessarily a perfect God because God is perfection. Hence, the existence of perfection indicates that God exists (p. 152).

6) Other topics highlighted by Prof. Dukor include anthropomorphism and imanism (i.e. describing God as if he is a man with human qualitied, especially that God is in all things, this which touched on what he called theistic panpsychic animistic universe) (i.e. God is the universe, the universe is God) (i.e. God is connected to all things through the gods, goddesses and divinities, down o the earth goddess-Ani-yet, God remains transcendant), (i.e. above all).

7) The mind and body issue in Ibo metaphysics simply holds that man is physical, spirit and mental (mind) in composition (see Eke, 2001), hence the question, what is the relationship between spirit, soul, heart and brain in man. According to Dukor, at death the Igbo spirit (muo) leaves the body (anu aru) and through transmigration that spirit metamorphoses into the soul (psyche) which goes to God for judgement (p. 157) The mind (mentality) cannot function if the spirit is not there since the spirit gives life and sustenance to the body, which energizes the mind; called Uche-muo, i.e. spiritual-mentality (intellect and consciousness).

8) Finally, other ontological objects in Igbo metaphysics include a) the mystical palm tree; b) The offor, symbol of truth; c) the ogiris, new boulda tree which represents personal and family totems (gods) etc. Then the Oji (kola nut). That is, he who brings the kola nut brings life.

Prof. Madu Dukor ended this chapter with notes on the philosophical significance of myths and symbols (case study) the Zangbeto cult of the Ogu people of Badagry, Nigeria; the significance has its origin in the religious humanism and the philosophical search for wisdom through premodial myths of the zangbeto tradition (p. 163).

\section{Research Findings, Suggestions and Conclusions}

This study has noticed that works in philosophy often focus on carving out ideologies, worldviews or believe-systems for groups or peoples; often these believe-systems end up sticking as those peoples' philosophies without measureable evidences of sociological or practical (pragmatic) relevance or solution of those peoples social-problem by the philosophies carved out or attributed to them. The point is that this study has found out that more often a peoples philosophies, theistic, humanist, phenomenological, or existential ideologies, do not really often improve the social and economic welfare of such people; which is what Humanism should be that is, a people's philosophy should be seen to be improving their socio-economic educational and scientific-wellbeing. This is what I am saying, if the Ibo are presented as egalitarian and capitalist in their philosophy. Can we presently identify prosperity and socio-scientific advancement among present day Ibos as a philosophy of hardwork, progressiveness, egalitarianism, capitalism and existentialism.

\section{Let Us Perform an Experiment}

1) Someone sat down in California, never visited Africa, but he wrote that Africans are "theistic existentialists".

2) Someone else visits some African communities and interacts with poor uneducated people (not western or university trained philosophers) Do you think that an uneducated African will understand what "theistic existentialism" means, let alone accept it as a worldview Cosmology or philosophy.

3) Then verbally interview and ask that poor uneducated farmer what his philosophy or view of life is; i.e. ask him what life means to him just wait for it.

4) What this experiment means is that often scholars sit down on study tables and label a peoples belief systems without visiting and interacting with such people. Often such people do not understand what such scholars have labeled them: but onething is often very clear. People know what they are worshipping. Often they do not think or reason the way other people say they do. Simply put, philosophers have become mind readers of what they believe people are reasoning, rather than being investigators of what people are actually reasoning.

\section{REFERENCES}

Aland, K., \& Newman, B. (1983). The Greek new testament: Greek lexicon (p. 130). Stuttgart: WBS.

Brown, R. K., \& Philip, W. C. (1990). Douglas: The new Greek-English interlinear new testament. Ilinois: Tyndale.

Dukor, M. (2010). Theistic humanism in African philosophy; the great debate on substance and method of philosophy (pp. 110-175). Saabruchekn: Lambert.

Eke, J. G. (2001). Igbo-English dictionary “Okowa Okwu” (p. 311). Enugu: New Generation.

Goodrich, K. (2010). Paul the Oikonomos of God. Ph.D. Thesis, Durham: Durham University.

Metzger, B. (2001). The new testament Greek. Illinois: Baker.

Nabofa, M. Y. (1996). Symbolism in African traditional religion. Ibadan: MYN.

Nnaji, O. C. (2011a). Religious statistics and estimation mathematics. Abuja: AJPR.

Nnaji, O. C. (2011b). Theometry; scientific philosophy of religion (pp. 74-75). Abuja: Theometry.

Nnaji, O. C. (2012). Origin and true meaning of philosophy. Abuja: Theometry.

The King James Version Bible Dictionary-Concordance (2001). Brussels: Thomas Nelson. 